

\title{
Short term performance analysis of IPOs in India
}

\author{
Naveen Ramesh Yadav ${ }^{a}$, \\ Hirak Dasguptab ${ }^{\mathrm{i}}$, Rashmy \\ Moray $^{b}$
}

${ }^{a}$ Senior Risk Analyst; Credit Suisse, Mumbai \& Alumnus, Symbiosis

Institute of Management Studies, Symbiosis International (Deemed)

University, Pune, India

${ }^{\mathrm{b}}$ Associate Professor; Symbiosis Institute of Management Studies,

Symbiosis International (Deemed) University, Pune, India

\ hirak.dasgupta@sims.edu Corresponding author

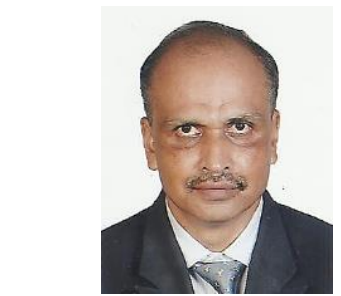

Corresponding author
ARTICLE HISTORY:

Received: 24-Aug-2018

Accepted: 17-Nov-2018

Online available: $03-\mathrm{Dec}-$

2018

\section{Keywords:}

IPO,

BSE,

NSE,

Risk,

Return,

Under pricing

\begin{abstract}
The research is aimed at the short term IPO returns that are issued on the National Stock Exchange (NSE) and Bombay Stock Exchange (BSE). The evaluation of IPO is done on the basis of the returns generated on the day of issue, 10 and 30 days after the day of issue. The significance of this paper can be realized from the fact whether the return generated in short term in comparison to the market are more or less i.e. the IPO has outperformed the index as a benchmark. The study includes a sample of 28 IPO's issued from the year 2013 to 2015. The results showed that the mean \% performance of IPO on the day of issue, 10 and 30 days after the day of issue is $9 \%, 10 \%$ and $10 \%$ respectively for NSE and $8 \%, 9 \%$ and $14 \%$ respectively for BSE. The above results are also supported with relative valuation index which thus brings us to a very important conclusion that the Indian Stock market provides significant returns within 30 days from the date of issue of share.
\end{abstract}

\section{Contribution/ Originality}

The research purely highlights on the possible short term returns generated by investors from IPOs in India`s 2 major stock exchanges NSE \& BSE. This contributes to the body of knowledge by enabling an equity investor to evaluate the risk and returns that can be expected by participating in IPOs. It also entails an investor to compare the investment returns from IPO in the first 30 days of listing with other fixed income securities.

DOI: 10.18488/journal.1007/2018.8.11/1007.11.392.403

ISSN (P): 2306-983X, ISSN (E): 2224-4425

How to cite: Naveen Ramesh Yadav, Hirak Dasgupta and Rashmy Moray (2018). Short term performance analysis of IPOs in India. Asian Journal of Empirical Research, 8(11), 392-403.

(C) 2018 Asian Economic and Social Society. All rights reserved 


\section{INTRODUCTION}

A robust financial system enables the lenders and suppliers of funds in a place called financial markets. A developed primary market is vital for resource mobilization bridging the gap between investors seeking investment opportunities and issuers seeking to mobilize resources to finance their businesses (Tyagi, 2016-17). The capital markets nurture the economic growth by channelization of savings for the purpose of capital formation and increases productivity of investment (Sanjay, 2013). The major source of capital is mobilised through the floatation of Initial Public Offerings (IPO). An IPO symbolizes a crucial shift in the company`s development-a transition that takes the privately held firm to the public dome (Certo, 2003). An IPO passes a strong positive signal to the world that the firm is about to enter into a period of growth by evaluating the investment options available and successfully employing the new capital raised. These signals result in an increase in the price of the stock on the day of IPO announcement that are considered as excess positive abnormal returns (Rebecca Abraham, 2016).

In recent past IPO has become a vital source of funds to the corporates that accelerates their growth and considered as one of the investment tool since the first day of listing of IPO offers profuse profits to the company. The IPO has been one of the lucrative options that investors have for investments. IPOs are often seen as a predictable opportunity to earn abnormal profits on the day of listing (Poornima, 2016). Each IPO is judged on the case by case basis but it is found that investors' appetite has increased due to their exceptional performance in recent past. According to Ernst and Young Global IPO Market Study Report: 2017 Review and 2018 Outlook, the year 2017 has closed with more IPO listings than any year since 2007. If we look at the global scenario 2017 has registered 1,624 IPOs with USD 188.8 billion raised globally- a year-on-year growth of $49 \%$ by the number of deals and $40 \%$ by capital raised. Although these figures do not meet the level of 2007 (1,974 IPOs with USD 338.4 billion of funds raised). The report says it would have been stronger at the global level but due to weaker than expected activity levels at Asia Pacific regions. Amongst these US, India, Australia, Japan and UK exchanges were the significant performers whereas Greater China contributed to $36 \%$ of globally funds raised. This shows an upward trajectory in the growth of global economy since the end of last financial crises. At the outset Indian IPO market too has shown heightened activities and have varied from year on year characterised by over whelming response to a majority of the public issues from foreign portfolio investors (FPIs), other institutional and the retail investors. In the last three years India IPO market gained revival momentum where it is evident that during 2014-15 Rs.19,202 crore of amount was mobilised through 70 companies floating IPO and 18 rights issues as against 90 companies which raised 55,652 crore in 2013-14 through 75 IPO and 15 rights issues. In the year 2014-15 88 companies floated IPOs but the amount mobilised was low though the number of companies floated in 2013-14 was on an average were the same. Whereas during 2016-17, 62,067 crores was mobilized through 122 public and 12 rights issues as against `57,866 crore raised in 2015 16 through 94 public and 13 rights issues. There was a quantum leap in the number of IPO and the amount mobilised. This indicates a substantial rise in the capital market as a mode of finance amongst the corporates, equally providing enormous opportunities for investors to invest in a cross-section of firms representing the growth economy. The amount raised through IPOs in 2016-17 nearly doubled by 96.4 per cent to`29,104 crore as compared to`14,815 crore during 2015-16.

The investors reaction to the stock markets depend on diverse factors. The investors base their stock purchase decisions on economic criteria (Merikas, 2003). They do not rely on a single integrated approach but on many macro and micro factors associated with economy, industry and company in particular. The investment decisions of an investors in an IPO market depends on past performance of the company's stock, expected stock split/capital increases/bonus, dividend policy, expected corporate earnings (Obamuyi, 2013). Infact it depends on the selection of stocks one makes on the basis of the information that investors tend to receive or gather through different sources. Information is one of the keys in making rational financial decisions (Tauni, 2017). Individuals do not possess sufficient financial literacy (Lusardi, 2007) and lack information related to financial markets but at the same time they acquire lot of information only if their utility increases and their portfolio performances 
improves (Guiso, 2007). The objective of every investor in the IPO market is to maximise the short term and long term returns. These returns are an outcome of investors' expectations, risk tolerance, and risk perception that affects the risk taking ability and investments in IPO (Arvid and Hoffmann, 2015). It is evident that stock prices respond to the information and the investors give high relevance to past performance.

The past studies literature illustrates that IPO of common stock produce more than normal returns on an average for investors who acquires the stock at the offer price. Logue (1965-69), Reilly (1987) and Ibbotson (1994) have cited examples in their research that provides empirical evidence of an extraordinary short-run return. Generally, it is an observed anomaly that the IPOs are underpriced, that means most of the IPO's on the day of issue gives abnormal returns. Under-pricing of IPOs has been a topic of theoretical investigations for decades (Welch, 2002). Under-pricing is estimated as the percentage difference between the price at which the IPO shares were sold to investors (the offer price) and the price at which the shares subsequently trade in the market (Ljungqvist, 2004). Several reasons have been deliberated on the underpricing of IPOs. The possibility could be the shares are issued at less than the market price as compared to the company peers, or company has created brand value and sustained brand equity. IPO issuers (Investment banker, financial intermediaries) are more informed about the demand more than investors that are based on the theories of asymmetric information and share the prediction that underpricing is positively related to the degree of asymmetric information (Baron, 1982). postulates the role of underwriters and intermediaries in enforcing the underpricing equilibrium. Many of the studies in the past have addressed the implications of these results for efficient market hypothesis(EMH). Consistent with the EMH, prices adjust with the underpricing and the investors who buy the new issued stocks in the secondary market (i.e. a week or fortnight or month after IPO) do not experience excess returns (Reilly, 1987). The underpricing phenomena endorses that the initial returns should be earned by the buyers who purchases shares in the initial offering rather than those who buy shares in the secondary markets (Barry, 1993). The short-run underpricing of IPOs is a well-documented deviation from market efficiency (Anna and Vong, 2010). As cited above numerous studies have shown that a significant first day return can be earned by investors during IPOs, Reilly (1987) and Ibbotson (1994) have documented list of possible explanations for underpricing, subsequently various other authors formally explored the work later (Ritter, 2002). More than normal returns on the first day if issue of IPO have confounded policy makers, academicians and practitioners. The hypothesis proposed by (Rock, 1986) received appealing attention. Investors were classified into informed and uninformed. Informed investors are able to decide on the offerings about their expected returns and the issue would likely be oversubscribed. Uninformed investors would receive some rationed amount in their response to issue. Where as in case of overpriced issue informed investors avoid participating in the issue allowing the uninformed investors to absorb the overpricing. He concludes the views held by the informed and uninformed investors about the underpricing of the IPO issued. The underpricing of the IPOs is similar to pull strategy created on the uninformed investors. If underpricing would not have existed, the uninformed investors will not have ever invested in fair and overvalued IPO's. This would have resulted in the failure of IPO's. Agarwal (1993) in their studies examined the short term and long term performance of IPO's by taking a sample of 62 from Brazil from 1980-1990, 36 from Chile from 1982-1990 and 44 from Mexico from 1987-1990. The research revealed that short term excess returns can be expected in Latin American market. The long term results for Brazil and Mexico shows significant overpricing of US IPO's. Ritter (2004) concluded that highest number of underpricing in IPO's is observed in developing economies. They also concluded that the long term performance of IPO has been marginally small. Roger et al. (1994) examined a total of 12028 samples from the period 1960-2008. The samples were taken from US Stock market. The extent of underpricing was found to be $17 \%$. On examining the strategic allocation of IPO. Kathaleen (1995) in the research reveals that Institutional Investors make major chunk of profits in IPO's. They conclude that US underwriters act strategically in allocation of IPO's. Philip and Lee (1996) examined the pricing in short and long run on Australian Stock Exchange and entailed that the relationship between initial and subsequent returns with respect to economic significance is low. The long term performance of IPO's listed on Australian Stock Exchange is low in comparison to the market movements. Seung (1998) compared the returns of privatization IPO's to privatized IPO's. The 
samples consist of 185 privatization IPO's selected from 30 countries from the period 1981 to 1997.The degree of underpricing was positively correlated to the stake sold at IPO. Kakati (1999) analysed short run under pricing and long term over pricing on the 500 IPO's issued from the year 1993 to 1996. It showed that the short run underpricing was to the extent of $36 \%$ and long run over pricing was to the extent of $40 \%$. Karolyi (2000) examined the long run return of non US firms raising capital in US via IPO. A sample of 333 IPO's are taken from 1982 to 1996. The long term performance of these non US entities is less in comparison to US entities when the same benchmark is used. Frederikslust (2001) in his analysis on IPO on long term performance and the samples taken from the period 1985-1998 from Amsterdam Stock Exchange comprising 38 private equity backed IPO and 68 non-private equity backed IPO. It reveals that underpricing is seen more in Private Equity backed firm than non-private equity backed firm. Chandrasekhar (2002) revealed underpricing to the extent of $72 \%$ from the samples of 386 IPOs issued in Indian Stock Market from the year 1992 to 1994. At the same time in Greek Stock exchanges the underpricing was to the extent of $64 \%$ that was found highest in manufacturing sector along with highest abnormal returns in IT sector. Gounopoulos (2003) considering the scenario in Euro New markets when the samples taken since the formation of Euro New Markets in the year 1996 revealed that underpricing is 2-3 times greater in comparison to the main market. Ranjan (2004) examined 92 samples of IPOs issued in Indian Stock Market from the year 1999 to 2003 . The underpricing was observed to the extent of $78 \%$ in fixed price issues and $2 \%$ for book built issues. When 53 samples for the period of 1990-2000 from Egyptian Stock Exchange were collected the research revealed underpricing to the extent of $8 \%$ (Omran, 2005). Pagett (2005) took 668 IPO from Chinese Stock Exchange for the period of 1996 to 2000 the underpricing was found to the extent of $129 \%$ due to and large number of uninformed investors. On the contrary a research based on investigating the IPO returns generated from Istanbul Stock Exchange from 1990 to 1997 postulates that the study did not find any evidence of underperformance in long term (Durukan, 2006) Researcher claim that firms with good financial health have great opportunity to raise additional capital (Bessler, 2007) and the firms with poor financial performance do not get second chance to sell the stocks to investors. Quayes (2008) investigated underpricing in the IPO's issued in Bangladesh Stock exchange taking 90 samples and were issued in mid-90. It revealed that the IPO's that were issued at premium were less underpriced than the IPO's that were issued at par. Haifeng and Brooks (2008) analysed the short term under performance of Chinese shares of category A for $10^{\text {th }}, 20^{\text {th }}, 30^{\text {th }}$ trading days ranging from the period from March 2001 to 2005. It reveals that the return obtained on day one was 94\%. Dismon (2009) examined the extent of underpricing on London Stock Exchange from 1959 to 2008 . Analysing the sample of 4198 IPOs and found $16 \%$ underpricing. The returns may vary from day one to day 30 of the IPO listed. Raheman's (2010) research entails that the average return obtained from the Karachi Stock Exchange are $42 \%, 41 \%, 37 \%, 38 \%$ and $39 \%$ on the $1^{\text {st }}, 5^{\text {th }}, 10^{\text {th }}, 15^{\text {th }}$ and $20^{\text {th }}$ day respectively on a study conducted on 73 IPO's issued on Karachi Stock Exchange from 200 to 2009. Subrahmanyam (2010) analysed 2811 IPO samples issued on Indian Stock Market from the year 1990 to 2007 the analysis revealed that the underpricing found was to the extent of $92.7 \%$. The underpricing of IPOs is referred to in the literature as one of the anomalies observed in primary markets all over the world. The extent of it, however, varies from country to country.

Most of the research done in the past signifies that on an average the IPO investors earn abnormal returns on the day of issue and thereby the subsequent days. Considering the historical trends, on the day of issue, there is high probability that the investors are able to earn enormous returns. All the rational investors look to a simple formula of buying cheap i.e. buying at low cost and selling dear i.e. selling at high cost. Based on the above literature the researcher has framed the following objectives and the manner through which these objectives can be achieved in Indian scenario. The research is aimed at the short term IPO returns that are issued on the National Stock Exchange (NSE) and Bombay Stock Exchange (BSE). The evaluation of IPO is done on the basis of the return generated on day of issue, 10 days after the day of issue and 30 days after the day of issue. The main objectives of the study are:

1) To calculate the logarithmic returns of IPO's on the issue day, 10 days after the day of issue and 30 days after the day of issue. This will help the investors to make a call whether they can earn 
positive returns in short run. Also to do hypothesis testing as to whether the mean return of IPO on day1, 10 days after the day of issue and 30 days after the day of issue equals 0 by using students t-distribution test for NSE as the number of samples are less than 30 and using z-test for BSE as the number of samples are more than 30 .

2) It also aims to help the investors to compare their returns with respect to benchmark rate offered by banks and enabling the investors to make decision about the investment. To achieve this, various ratios such as Sharpe Ratio, Treynor Ratio and Jenson's alpha on the day of issue, 10 days after the day of issue and 30 days after the day of issue are found out.

3) To compare the IPO's return on the year on year basis from the year 2013 to 2015 and compare the IPO's return on two stock exchanges i.e. NSE and BSE.

The significance of this paper can be realized from the fact whether the return generated in short term in comparison to the market are more or less i.e. the IPO has outperformed the index as a benchmark. The research paper explains the valuation techniques used for estimating the short term performance of IPO's with respect to index on which the shares are issued. The research paper will also help the investor to gain insights as to when is the right time for the investor to buy or sell the stock. The research paper also investigates the performance of IPO's in the past 3 years.

\section{SAMPLE AND DATA COLLECTION}

The total number of IPO's on NSE from the year 2013 to 2015 is 32 in number. Out of these 32 IPO's, there were 4 issues where the issue was withdrawn by the firm. So, the sample consists of 28 IPO's issued from the year 2013 to 2015. The total number of IPO's on BSE from the year 2013 to 2015 was 106 in number. Out of these IPO's, there was 1 issue where the issue was withdrawn by the firm. So, the sample consists of 105 IPO's issued from the year 2013 to 2015. The opening and closing date for the samples under NSE and BSE are from January 1, 2013 to December 31, 2015. The market index used as benchmark for NSE data samples is S\&P CNX NIFTY50 and for BSE data samples is S\&P BSE SENSEX. Thus, from the website of NSE i.e. https://www.nseindia.com, the closing values for both the stock and the market indexes on the issue day, 10 days after the day of issue and 30 days after the day of issue are considered for analysis. The opening IPO value along with opening market index value on the day of issue are considered for analysis. Similar methodology has been used for the BSE samples. The mean returns are then computed for the issue of share on all the respective days i.e. on the day of issue, 10 days after the issue and 30 days after the issue. This is done on year on year basis. This is also computed for all the 3 years for the respective days from the day of issue. In data collection, if the data is not available for a particular date, then the data for the immediate previous date is taken. Thus, while collecting the data, the company must satisfy the given conditions:

1. The company must be listed for the first time on the stock exchanges i.e. NSE and BSE

2. Also the data related to issue price and closing price are taken from NSE and BSE website for analysis.

3. The companies that have withdrawn their issues from the exchange are not considered for analysis.

\section{CONCEPTUAL FRAMEWORK}

The methodology used for understanding the short term performance of IPO's is based on the simple statistical and mathematical tools.

Returns for stock and market on the day of issue, 10 days after the issue and 30 days after the issue is estimated as follows:

The logarithmic return for the stock at the end of nth day is calculated by using the formula:

$$
R_{s, n}=\operatorname{Ln}\left(P_{l} / P_{0}\right)
$$


Where,

$\mathrm{R}_{\mathrm{s}, \mathrm{n}}$ is the logarithmic return at the end of $\mathrm{n}_{\text {th }}$ day from issue

$\mathrm{P}_{1}$ is the closing price of the stock after $\mathrm{n}$ days from the date of issue

$\mathrm{P}_{0}$ is the issue price of the stock on the day of issue

The logarithmic return for the market index at the end of nth day is calculated by using the formula:

$$
R_{m, n}=\operatorname{Ln}\left(M_{1} / M_{0}\right)
$$

Where,

$\mathrm{R}_{\mathrm{m}, \mathrm{n}}$ is the logarithmic return from the market index at the end of $\mathrm{n}_{\text {th }}$ day from issue

$\mathrm{M}_{1}$ is the closing market index on $\mathrm{n}$ days from the day of issue

$\mathrm{M}_{0}$ is the closing market index on the day of issue

The same calculation can also be done as follows:

The $\%$ return of IPO on the day of issue, 10 days after the issue date and 30 days after the issue date are calculated using following formula:

$\%$ Return of IPO $=($ Closing Price - Issue Price $) /$ Issue Price

The $\%$ return of market index on the day of issue, 10 days after the issue date and 30 days after the issue date are calculated using the following formula:

$\%$ Return of Market Index $=($ Closing Market Index - Opening Market Index $) /($ Opening Market Index)

After calculating the \% return of all IPOs, \% return of Market index for the corresponding date of issue of the IPO, we calculate the mean \% return of IPO and Market Index.

The $\%$ return of IPO is calculated using the following formula:

$$
\% \text { return }=\left\{\left(1+R_{s, n}\right) /\left(1+R_{m, n)}\right\}-1\right.
$$

In this case, the performance of IPO is adjusted with market return or the performance of IPO is measured considering the market return as benchmark.

The above formula is calculated for all the IPO's on day of issue, 10 days after the day of issue and 30 days after the day of issue.

After Calculating the \% return for each of the IPO's, mean value is taken for the return which will be then used for hypothesis testing

Mean return of IPO $=$ Sum $($ Mean return of IPO) $/$ Number of IPO

After Calculating the return for each of the market index, mean value is taken for the \% performance of market Index

Mean Return of Market Index = Sum (Return of Market Index) / Number of observation

Relative Valuation Index is used to calculate the near term performance of IPO by using the formula as follows:

$\mathrm{RVI}=(1+$ Mean return of IPO $) /(1+$ Mean return of Market Index $)$

When Relative Valuation Index is greater than 1, it means that the IPO has performed better than the market during the particular period of study.

When Relative Valuation Index is less than 1, it means that the IPO has performed poorly as compared to the market during the particular period of study.

The risk free rate and expected market return is obtained from http://www.market-riskpremia.com/in.html. The risk free rate and the expected market return are taken for $1^{\text {st }}$ of January of the year 2013, 2014 and 2015 and is assumed to be constant throughout the year. 
In order to calculate Sharpe Ratio, Treynor Ratio and Jenson's alpha, the other data that needs to be found out Standard Deviation of \% return of IPO, Covariance of market return and IPO return, Variance of Market.

The Beta of the IPO is then calculated using the formula:

Beta of IPO = Covariance (IPO return, Market Return)/ Variance (Market)

Sharpe ratio indicates the excess return that IPO earns over risk free rate with respect to the risk (standard deviation) of returns of IPO. It is calculated using the formula:

Sharpe Ratio $=($ Mean IPO return - Risk free rate $) /($ Std Deviation of IPO return $)$

Treynor Ratio indicates the excess return that the IPO earns over risk free rate with respect to systematic risk (Beta) that IPO of the company carries. It is calculated by formula:

Treynor Ratio $=($ Mean IPO return - Risk free rate $) /($ Beta of company going public $)$

Jenson's alpha indicates the excess return that the IPO earns over the expected return The Expected return is calculated using Capital Asset Pricing model formula:

Expected Return $=$ Risk Free Rate + Beta $*($ Expected Market Return - Risk Free Rate $)$ Jenson's Formula $=$ Mean IPO return - Expected Return

\subsection{Hypothesis testing}

The Hypothesis testing used for analyzing the mean return is t-test for NSE samples and z-test for BSE samples.

NSE Sample testing:

Ho : Mean return $=0$

$\mathrm{H} 1$ : Mean return not $=0$

The t-statistic is estimated using the following formula:

$\mathrm{t}=($ Mean return -0$) /(\operatorname{Std}$ Deviation/ Sqrt(No of IPOs $))$

BSE Sample testing:

Ho : Mean return $=0$

$\mathrm{H} 1:$ Mean return not $=0$

The $\mathrm{z}$-statistic is estimated using the following formula:

$\mathrm{Z}=($ Mean return -0$) /($ Std Deviation/ Sqrt(No of IPOs $))$

The level of significance assumed for both the test is $5 \%$ which means that the confidence interval comes out to be $95 \%$.

\section{ANALYSIS AND RESULTS}

Table 1: Year wise mean IPO return from the year 2013 to 2015 for NSE

\begin{tabular}{lccc}
\hline Particular & $\mathbf{2 0 1 3}$ & $\mathbf{2 0 1 4}$ & $\mathbf{2 0 1 5}$ \\
\hline Number of IPO's & 3 & 5 & 20 \\
Mean IPO return on day 1 & $2.14 \%$ & $26.52 \%$ & $8.81 \%$ \\
Mean IPO return on day 10 & $0.40 \%$ & $36.67 \%$ & $10.67 \%$ \\
Mean IPO return on day 30 & $0.34 \%$ & $36.75 \%$ & $10.45 \%$ \\
Mean Market index return on day 1 & $0.00 \%$ & $0.30 \%$ & $-0.17 \%$ \\
Mean Market index return on day 10 & $-2.55 \%$ & $1.28 \%$ & $0.01 \%$ \\
Mean Market index return on day 30 & $-0.91 \%$ & $3.74 \%$ & $-0.59 \%$ \\
\hline
\end{tabular}


From the above table, the interpretation is that the number of IPO's has increased from the year 2013 to 2015 from 3 to 20 . The total number of samples for the 3 years is equal to 28. Also the Mean \% IPO return on the day of issue of shares is more than $2 \%$. The year 2014 has shown the maximum gain in the IPO investment in comparison to the market return obtained in the same period. Sluggish growth is shown by IPO's in 2013. A moderate growth can be seen in the IPO's in the year 2015.As it can be seen from the above diagram, the market return has been low in the year 2013 and 2015. In 2014, the major factor that brought growth in the market returns and IPO return is the faith of the investor in the new government elected at the Centre.

Table 2: Year wise mean IPO return from the year 2013 to 2015 for BSE

\begin{tabular}{lccc}
\hline Particular & $\mathbf{2 0 1 3}$ & $\mathbf{2 0 1 4}$ & $\mathbf{2 0 1 5}$ \\
\hline Number of IPO's & 31 & 39 & 35 \\
Mean IPO return on day 1 & $16.52 \%$ & $8.17 \%$ & $6.34 \%$ \\
Mean IPO return on day 10 & $20.60 \%$ & $10.77 \%$ & $11.07 \%$ \\
Mean IPO return on day 30 & $40.04 \%$ & $11.16 \%$ & $29.14 \%$ \\
Mean Market index return on day 1 & $-0.09 \%$ & $-0.14 \%$ & $-0.37 \%$ \\
Mean Market index return on day 10 & $-0.10 \%$ & $1.31 \%$ & $-0.49 \%$ \\
Mean Market index return on day 30 & $1.72 \%$ & $3.27 \%$ & $-1.79 \%$ \\
\hline
\end{tabular}

From the above table, it can be interpreted that the number of IPO's has increased from the year 2013 to 2015 from 31 to 35 .The maximum number of IPO issue was found in the year 2015. The total number of samples for the 3 years is equal to 105. It can be seen from table that within 10 days after the issue of shares, the improvement of the newly issued shares is significantly high in comparison to the share value on the day of issue. The same can also be interpreted for shares value after 30 days of issue. The return for the market on the other side has been low. Thus, the return which we got by investing in IPO in comparison to market index is surpassed. The number of IPO's in the year 2014 has increased significantly high for the year 2014 due to the confidence of the investors in the new government.

Table 3: Consolidated mean IPO return for NSE and BSE

\begin{tabular}{lcc}
\hline Particular & NSE & BSE \\
\hline Number of IPO's & 28 & 105 \\
Mean IPO return on day 1 & $11.25 \%$ & $10.02 \%$ \\
Mean IPO return on day 10 & $14.21 \%$ & $13.78 \%$ \\
Mean IPO return on day 30 & $14.07 \%$ & $25.68 \%$ \\
Mean Market index return on day 1 & $-0.07 \%$ & $-0.2 \%$ \\
Mean Market index return on day 10 & $-0.04 \%$ & $0.29 \%$ \\
Mean Market index return on day 30 & $0.15 \%$ & $1.13 \%$ \\
\hline
\end{tabular}

From the above table, it can be interpreted that if the investors wants to make a short time investment of a day in the stock and exit its position at the end of day, investing in NSE will be a good option as the returns given by $11.25 \%$ which is more than the return generated by the IPO issued on BSE. If we consider an investment in the stock for duration of 30 days, investing in BSE will be better option than investing in NSE as the returns fetched in 30 days duration is $25.68 \%$ which is more than the returns obtained by investing in NSE.

Table 4: Consolidated descriptive statistics for past 3 years for NSE

\begin{tabular}{lcccc}
\hline Trading Day & Mean Return & $\begin{array}{c}\text { Std Deviation of } \\
\text { Return }\end{array}$ & $\begin{array}{c}\text { Minimum } \\
\text { Return }\end{array}$ & $\begin{array}{c}\text { Maximum } \\
\text { Return }\end{array}$ \\
\hline Day 1 (IPO) & $9 \%$ & 0.1851 & $-19 \%$ & $53 \%$ \\
Day 10 (IPO) & $10 \%$ & 0.2382 & $-20 \%$ & $73 \%$ \\
Day 30 (IPO) & $10 \%$ & 0.2521 & $-33 \%$ & $64 \%$ \\
\hline
\end{tabular}




\begin{tabular}{llllc}
\hline Day 1 (Market) & $-0.07 \%$ & 0.0102 & $-2.64 \%$ & $3.08 \%$ \\
Day 10 (Market) & $-0.04 \%$ & 0.0283 & $-4.13 \%$ & $9.16 \%$ \\
Day 30 (Market) & $0.15 \%$ & 0.0509 & $-8.88 \%$ & $15.03 \%$ \\
\hline
\end{tabular}

The mean return obtained by investing in IPO is $9 \%$ on the day of issue with standard deviation as low as 0.18516 . If we compare the Return/Std deviation then the investment is more valuable on NSE if we do it on the first day as compared to the $10^{\text {th }}$ day and $30^{\text {th }}$ day. The minimum $\%$ return obtained from the IPO investment is on day and the maximum return is obtained by making the investment on day 10 i.e. $73 \%$.

Table 5: Consolidated descriptive statistics for past 3 years for BSE

\begin{tabular}{lcccc}
\hline Trading Day & Mean Return & $\begin{array}{c}\text { Std Deviation of } \\
\text { Return }\end{array}$ & $\begin{array}{c}\text { Minimum } \\
\text { Return }\end{array}$ & $\begin{array}{c}\text { Maximum } \\
\text { Return }\end{array}$ \\
\hline Day 1 (IPO) & $8 \%$ & 0.1755 & $-32 \%$ & $123 \%$ \\
Day 10 (IPO) & $9 \%$ & 0.2356 & $-45 \%$ & $144 \%$ \\
Day 30 (IPO) & $14 \%$ & 0.3717 & $-82 \%$ & $147 \%$ \\
Day 1 (Market) & $-0.2 \%$ & 0.0081 & $-2.55 \%$ & $1.63 \%$ \\
Day 10 (Market) & $0.29 \%$ & 0.0304 & $-5.67 \%$ & $7.95 \%$ \\
Day 30 (Market) & $1.13 \%$ & 0.0442 & $-9.12 \%$ & $11.08 \%$ \\
\hline
\end{tabular}

For BSE, the mean IPO return is minimum on the day of issue i.e. $8 \%$ and its maximum on the 30 days after the issue of shares. Also the risk associated with investors has increased from 0.175568 to 0.371714. So, the recommendation for the investor will be based purely on Risk Vs Return i.e. depending on the risk the investor is willing to take, the investor will get the corresponding return. The maximum loss will occur on 30 days after the issue and minimum loss will be suffered will be on the day of issue of shares. The maximum \% return will be obtained after 30 days of issue. The return which the investor will get by investing in IPO on the day of issue will be $123 \%$.

Table 6: Ratio analysis and Hypothesis testing for NSE samples

\begin{tabular}{lccccc}
\hline Trading Day & $\begin{array}{c}\text { Relative } \\
\text { Valuation Index }\end{array}$ & T-statistic & Sharpe Ratio & $\begin{array}{c}\text { Treynor } \\
\text { Ratio }\end{array}$ & $\begin{array}{c}\text { Jenson's } \\
\text { Alpha }\end{array}$ \\
\hline Day 1 & 1.0517 & 2.5671 & 0.5085 & 0.0377 & $11.20 \%$ \\
Day 10 & 1.0589 & 2.2895 & 0.4665 & 0.0729 & $14.16 \%$ \\
Day 30 & 1.0602 & 2.1797 & 0.4877 & 0.3288 & $14.03 \%$ \\
\hline
\end{tabular}

The relative valuation index for the IPO with respect to market return is greater than 1 for short term i.e. on day1, day 10 and day 30 from issue which means that the IPO performance has surpassed the performance of market on corresponding days from the date of issue. The critical t-value required for the rejection of null hypothesis is 2.052 . The t-statistic calculated using the formula mentioned in research methodology is more than 2.052 which means that the null hypothesis can be rejected i.e. $95 \%$ of the time we invest in IPO; we will have the possibility of earning more than $0 \%$ return. The Sharpe ratio obtained on day 1 , day 10 and day 30 from the issue date is on an average 0.5 which means that the excess return over the risk free rate of the IPO is half of the risk the investor is willing to take. The Treynor ratio has increased significantly from day 1 , day 10 to day 30 of issue. This increase is due to fall in the beta.

Table 7: Ratio analysis and Hypothesis testing for BSE samples

\begin{tabular}{lccccc}
\hline Trading Day & $\begin{array}{c}\text { Relative } \\
\text { Valuation Index }\end{array}$ & Z-statistic & Sharpe Ratio & $\begin{array}{c}\text { Treynor } \\
\text { Ratio }\end{array}$ & $\begin{array}{c}\text { Jenson's } \\
\text { Alpha }\end{array}$ \\
\hline Day 1 & 1.0517 & 2.5671 & 0.3618 & 0.0326 & $9.96 \%$ \\
Day 10 & 1.0589 & 2.2895 & 0.3661 & 0.2931 & $13.74 \%$ \\
Day 30 & 1.0602 & 2.1797 & 0.4100 & 5.3146 & $25.65 \%$ \\
\hline
\end{tabular}


The Relative Valuation Index for IPO with respect to market return is greater than 1 which means that the return obtained from investing in the new shares listed on BSE is more than the performance of market index. The critical $z$-value required for the rejection of null hypothesis at $5 \%$ confidence interval is 0.95 . The $\mathrm{z}$-statistic calculated using formula mentioned in the research methodology is more than 2 which means that $95 \%$ of the time we invest in the IPO's, we will get the return of more than $0 \%$. The Sharpe ratio obtained for all the days is approximately equal to 0.4 which means that the excess return over risk free rate is 0.4 times of standered deviation of returns of IPO on the respective days from the date of issue. The Treynor ratio has increased significantly from 0.03 on the day of issue to 5.314672 after 30 days of issue. The main factor responsible for this increase is the fall in the beta value of the company for which beta values are calculated. The Jenson's alpha has increased from $9.96 \%$ on the day of issue to $25.65 \%$ which is nothing but the returns obtained in excess of expected return obtained from CAPM (Capital Asset Pricing model).

\section{CONCLUSION}

The study was done to understand the near term IPO performance. In order to achieve this we have obtained returns on the day of issue, 10 days after the date of issue and 30 days after the date of issue. The research paper will help the investor to understand when is the right time for investor to make an exit from the time the investment is made and how much average return the investor can make if he exits its position on the stock. It can be seen that returns obtained by investing in the IPO issued on NSE is more than the return obtained by investing in the IPO issued on BSE. If we make the investment for 30 days of duration, the return obtained from BSE is more than the return obtained from NSE. The IPO's offered average positive returns on the day of issue, 10 days after the day of issue and 30 days after the day of issue irrespective of the stock exchange on which the stock is been issued. This result is in contrary to the past result which reveals that the IPO's underperform after 30 days of issue. The above research paper will help the investor to make required returns if they buy the stocks and sell them at right time. The mean $\%$ performance of IPO on the day of issue, 10 days after the day of issue and 30 days after the day of issue is $9 \%, 10 \%$ and $10 \%$ respectively for NSE and $8 \%, 9 \%$ and $14 \%$ respectively for BSE. The above results are also supported with relative valuation index which thus brings us to a very important conclusion that the Indian Stock market provides abnormal returns within 30 days from the date of issue of share. If we do year wise analysis, the year 2014 provided good results for the IPO investors who invested in NSE. The year 2013 provided good results for the IPO investors who invested in BSE.

\section{Funding: This study received no specific financial support.}

Competing Interests: The authors declared that they have no conflict of interests.

Contributors/Acknowledgement: All authors participated equally in designing and estimation of current research.

Views and opinions expressed in this study are the views and opinions of the authors, Asian Journal of Empirical Research shall not be responsible or answerable for any loss, damage or liability etc. caused in relation to/arising out of the use of the content.

\section{References}

Anna, P. I., \& Vong a, D. T. (2010). The short-run price performance of initial public offerings in Hongkong: New Evidence. Global Finance Journal, 21, 253-261. Retrieved from journal home page: $\underline{w w w . e l s e v i e r . c o m / l o c a t e / g f j}$.

Arvid, O. I. \& Hoffmann, T. P. (2015). How investor perceptions drive actual trading and risk taking ability. Journal of Behavioral Finance, 16, 97-103. view at Google scholar / view at publisher

Barry, B. C. (1993). He opening price performance of initial public offering of common stock. financial management. Financial Management, 22(1), 54-63. view at Google scholar / view at publisher

Baron, D. P. (1982). A model of the demand for investment banking advising and distribution services for. The Journal of Finance, 37(4), 955-976. 
Bessler, W. (2007). The Long run performance of Initial Public Offereings in Germany. Managerial Finance, 33(6), 420-441. view at Google scholar / view at publisher

Certo, T. (2003). Influencing initial public offering, investors with prestige: signaling with board structures. Academy of Management Review, 28(3), 432- 446. view at Google scholar

Chandrasekhar, K. P. K. (2002). The initial listing performance of Indian IPOs. Managerial Finance, 28(2), 39-51. view at Google scholar / view at publisher

Dismon, D. C. (2009). IPO Underpricing over the Very Long Run. The Journal of Finance, 64(3), 1407-1443. view at Google scholar / view at publisher

Durukan, M. B. (2006). IPO underpricing and ownership structure: Evidence from the Istanbul Stock Exchange. In M. B. Durukan, Initial Public Offerings, an International Perspective (pp. 263278). Elsevier. view at Google scholar / view at publisher

Reilly, F. K. R. A. (1987). An examination of mispricing, returns, and uncertainity for initial public offereings. Financial Management, 16(2), 33-38. view at Google scholar

Frederikslust, R. V. (2001). Initial returns and long-run performance of private equity-backed initial public offerings on the Amsterdam stock exchange. EFMA 2001 Lugano Meetings, 31. view at Google scholar / view at publisher

Subrahmanyam, V. B. G. (2010). Group affiliation and the performance of IPOs in the Indian stock market. Journal of Financial Markets, 13(1), 196-223. view at Google scholar / view at publisher

Gounopoulos, D. (2003). The initial performance of Ipos: Evidence from Athens stock exchange. EFMA 2003 Helsinki Meetings, 1-50. view at Google scholar / view at publisher

Guiso, 1. A. (2007). Information acquiaition and portfolio performance. EUI Working Papers. European Department Institute: EUI, Dept of Economics. Retrieved from http://cadmus.eui.eu.

Haifeng, G., \& Brooks, R. (2008). Underpricing of Chinese A-share IPOs and short-run underperformance under the approval system from 2001 to 2005. International Review of Financial Analysis, 17(5), 984-997. view at Google scholar / view at publisher

Kakati, M. (1999). Price performance of initial public offerings. International Journal of Development Banking, 17, 59-75. view at Google scholar

Karolyi, S. R. (2000). The long-run performance of global equity offerings. Journal of Financial and Quantitative Analysis, 35(4), 499-528. view at Google scholar

Kathaleen, W. J. (1995). Evidence on the strategic allocation of initial public offerings. Journal of Financial Economics, 37(2), 239-257. view at Google scholar

Ljungqvist, A. (2004). Empirical corporate finance. In A. Ljungqvist, \& B. E. Eckbo (Ed.), Empirical Corporate Finance (pp. 1-76). Stern School of Business. Retrieved from file:///C:/Users/DrRashmyMoray/Downloads/SSRN-id609422.pdf.

Logue, D. (1965-69). Premia on unseasoned equity issues. Journal of Economics and Business, 25, 133-141. view at Google scholar

Lusardi, A. A. (2007). Baby boomer retirement security: the roles of planning, financial literacy, and housing wealth. Journal of Monetary Economics, 54(1), 205-224. Retrieved from https://www.sciencedirect.com/science/article/pii/S0304393206002467.

Merikas, A. (2003). Factors inlfuencing Greek investors behaviour on Athens Stock Exchange. Academy of Financial Services. Denver, Colorado.

Obamuyi, T. M. (2013). Factors influencing investment decisions in capital market: a study of individual investors in Nigeria. Organisations and Markets in Emerging Economy, 1(7), 141161. Retrieved 2018, from https://www.ceeol.com/search/article-detail?id=266579.

Omran, M. (2005). Underpricing and long-run performance of share issue privatizations in the Egyptian stock market. The Journal of Financial Research, 28(2), 215-234. view at Google scholar / view at publisher

Pagett, J. C. (2005). Short-run underpricing and its characteristics in Chinese initial public offering (IPO) markets. Research in International Business and Finance, 19(1), 71-93. view at Google scholar / view at publisher

Philip, J., \& Lee, S. L. (1996). Australian IPO pricing in the short and long run. Journal of Banking and Finance, 20, 1189-1210. view at Google scholar 
Poornima, S. (2016). A study on the performance of initial public offering of companies listed. International Journal of Research in Finance and Marketing (IJRFM), 6(11), 31-47. Retrieved March 2018, from http://www.euroasiapub.org.

Quayes, T. H. (2008). Underpricing of initial public offerings in Bangladesh. Applied Financial Economic Letters, 4, 5-8. view at Google scholar / view at publisher

Ibbotson, R. (1994). Price performance of common stock new issues. Journal of Financial Economics, 2(3), 66-74. view at Google scholar

Raheman, M. K. (2010). Examining the short-run IPOs performance in state of economy: normal, boom \& recession. International Research Journal of Finance and Economics, 35, 173-186. view at Google scholar

Ranjan, N. A. (2004). IPO underpricing, Issue Mechanisms, and Size. Working Paper Series. view at publisher

Rebecca Abraham, J. H. (2016). IPO performance at Announcement and in the Aftermarket. Journal of Economic Studies, 43(4), 574-586. view at Google scholar / view at publisher

Reena Agarwal, R. L. (1993). The after market performance of initial public offerings. Financial Management, 22(1), 42-53.

Ritter, I. W. (2002). A review of IPO activity, pricing and allocations. The Journal of Finance, 57(4), 1795-1828. view at Google scholar

Ritter, L. A. (2004). Why IPO underpricing has changed overtime? Financial Management, 33, 5-37. view at Google scholar

Rock, K. (1986). Why new issues are underpriced? Journal of Financial Economics, 15(1-2), 187212. view at Google scholar / view at publisher

Roger, G. Ibbotson, J. L., \& Sindelar, J. R. R. (1994). The market's problems with the pricing of initial public offerings. Journal of Applied Corporate Finance, 7(1), 66-74. view at Google scholar I view at publisher

Sanjay, B. K. (2013). Valuation of IPOs in India-an empirical study. Business and Economic Research, 3(2), 1-22. view at Google scholar / view at publisher

Seung, S. K. (1998). The short run performance of Ipos of privately and publicly owned firms: international evidence. Multinational Fianncial Journal, 2(3), 225-244. view at Google scholar

Tauni, M. Z. (2017). Does investor personality moderate the relationship between information sources and trading behavior? Evidence from Chinese stock market. Managerial Finance, 43(5), 545566. view at Google scholar / view at publisher

Tyagi, A. (2016-17). Annual report. Securiies exchange board of India. GOI, Department of Economic Affairs, Ministry of Finance. Retrieved from https://www.sebi.gov.in/sebi_data/attachdocs/oct-2017/1509355227171.pdf.

Welch, J. R. (2002). A Review of IPO activity, pricing, and allocations. Journal of Finance, 57(4), 1795-1828. Retrieved 2018 http://www.market-risk-premia.com. 